\title{
Measurement of Natural Radioactivity in Sand Samples Collected from Ad-Dahna Desert in Saudi Arabia
}

\author{
Abdulaziz S. Alaamer \\ Department of Physics, Al-Imam Mohammad Ibn Saud Islamic University (IMSIU), Riyadh, KSA \\ Email: alaamer@hotmail.com
}

Received September 13, 2012; revised October 15, 2012; accepted October 24, 2012

\begin{abstract}
Natural radioactivity is a source of continuous exposure to human beings. The natural radioactivity due to the presence of ${ }^{226} \mathrm{Ra},{ }^{232} \mathrm{Th}$ and ${ }^{40} \mathrm{~K}$ in sand samples collected from Ad-Dahna was measured by means of HPGe. The measured activity concentrations of radionuclides were compared with the worldwide reported data. Mean measured activity concentrations of ${ }^{226} \mathrm{Ra},{ }^{232} \mathrm{Th}$ and ${ }^{40} \mathrm{~K}$ varied between $16.2-30.6,15.8-36.7$ and $285.3-533.2 \mathrm{~Bq} \cdot \mathrm{kg}^{-1}$ respectively with a mean value of $23.4 \pm 4.3 \mathrm{~Bq} \cdot \mathrm{kg}^{-1}, 29.7 \pm 5.9 \mathrm{~Bq} \cdot \mathrm{kg}^{-1}$ and $380 \pm 65 \mathrm{~Bq} \cdot \mathrm{kg}^{-1}$ respectively. Mean values of radium equivalent activity, absorbed dose rate and external radiation hazard index were $106 \pm 8 \mathrm{~Bq} \cdot \mathrm{kg}^{-1}, 51.4 \mathrm{nGy} \cdot \mathrm{h}^{-1}$ and 0.29 respectively. The annual effective radiation dose was calculated to be $0.32 \mathrm{mSv}^{\cdot} \mathrm{y}^{-1}$. The $\mathrm{Ra}_{\mathrm{eq}}$ values of sand samples are lower than the limit of $370 \mathrm{~Bq} \cdot \mathrm{kg}^{-1}$, equivalent to a gamma dose of $1.5 \mathrm{mSv} \cdot \mathrm{yr}^{-1}$. This study shows that the measured sand samples do not pose any significant source of radiation hazard and are safe for use in building materials.
\end{abstract}

Keywords: Natural Radioactivity; Sand; Gamma-Ray Spectrometry; Dose Rate; Ad-Dahna

\section{Introduction}

Naturally occurring radioactive materials (NORM) is wide spread in the earth's environment. The presence of natural radioactivity in soil and other building materials results in internal and external exposure to the occupants. NORM existing in soil could pose potential health physics risk [1]. Terrestrial radioactivity, and the associated external exposure due to the gamma radiation depend primarily on the geological and geographical conditions and appear at different levels in the soils of each region $[1,2]$. The largest contribution to the radiation field is due to the cosmic rays, the natural radionuclides in soil, radioactivity of the ground and the radioactive decay products of radon in the air. Under normal conditions, artificial radioactivity emitted from the nuclear power plants, industrial plants and research facilities has smaller contribution to the overall radiation. Natural environmental radioactivity arises mainly from primordial radionuclides, such $a^{226} \mathrm{Ra},{ }^{232} \mathrm{Th},{ }^{40} \mathrm{~K}$ and their decay products, which occur at trace levels in all ground formations [4]. Accumulation of these radionuclides in the environment raises many problems concerning safety of biotic life, food chain and ultimately humans. To address these problems, it is necessary to know the dose limits of public exposures and to measure the natural environmental radiation level for the estimation of the exposures to natural radiation sources [5]. Many studies have investigated the lev- els of natural background radiationby in situ measurements or by analysis of radionuclideconcentration in sand samples [6-15].

Desert is the most prominent feature of Arabian Peninsula of which Saudi Arabia is the largest country (Figure 1). About 35\% of the land in Saudi Arabia is covered by sandy-deserts. The country has three major deserts. Rub-al-Khali extends over much of the southeast and beyond the southern frontier. Rub-al-Khali has an estimated area of about $650,000 \mathrm{~km}^{2}$. An-Nafud is an upland desert of red sands, due to iron oxide coating, covering an area of $64,000 \mathrm{~km}^{2}$. It lies at an elevation of 900 meters in the northern part of Saudi Arabia. Ad-Dahna is a narrow strip of sandy terrain. This reddish sandy desert is in the central Saudi Arabia, extending about $1300 \mathrm{~km}$ southward from the northeastern edge of An-Nafud to the northwestern borders of Rub-al-Khali. The sand available along Ad-Dahnais used as a construction material. Therefore, radiometric characterization provides a useful technique of acquiring better knowledge of the local environment and radiation doses to be received by the general public [16].

\section{Materials and Methods}

Sand samples were collected from twenty three sites of Ad-Dahna desert around Riyadh City. At every sampling site, samples were collected from about $30 \mathrm{~cm}$ deep of 


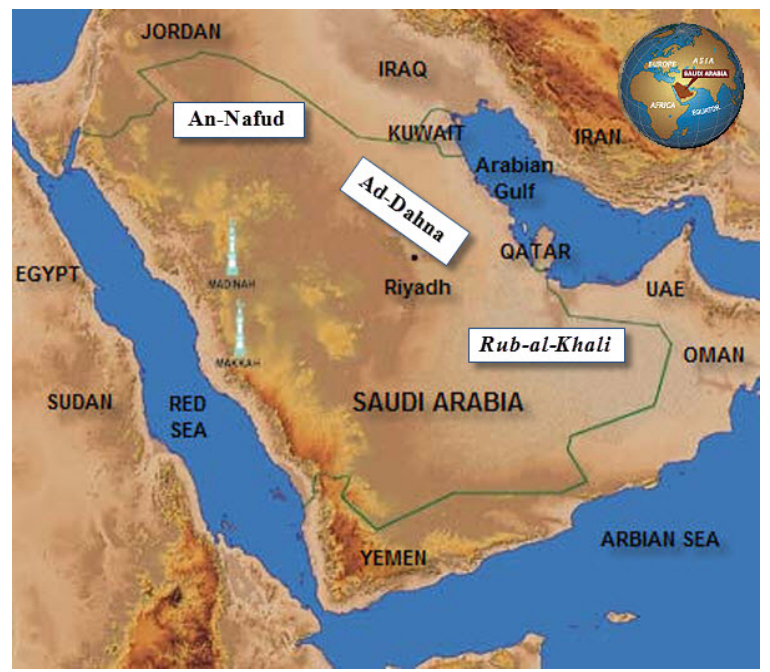

Figure 1. Maps of deserts in Saudi Arabia.

four corners and the center of a square area corresponding to $1 \mathrm{~m}^{2}$. The five samples were mixed together in situ; and this sand mixture, weighing approximately $1.25 \mathrm{~kg}$, was considered representative of the sampling site [13]. They were placed in plastic bags, labeled and carried to the laboratory. They were oven dried at a temperature of $110^{\circ} \mathrm{C}$ for 12 hours, and sieved through a $1 \mathrm{~mm}$ mesh. A $200 \mathrm{~g}$ of the homogenous samples were then packed in standard Marinelli beakers, weighed and carefully sealedto prevent the escape of gaseous ${ }^{222} \mathrm{Rn}$ and ${ }^{220} \mathrm{Rn}$ from the samples. They were stored for at least 4 weeks before counting to allow time for ${ }^{238} \mathrm{U}$ and ${ }^{232} \mathrm{Th}$ to reach equilibrium with their respective radionuclide daughters [17]. The measurement of activity concentrations of naturally occurring radionuclides of ${ }^{238} \mathrm{U}{ }^{226} \mathrm{Ra},{ }^{232} \mathrm{Th}$ and ${ }^{40} \mathrm{~K}$ in the samples were carried out using a high purity germanium (HPGe) detector coupled with a multi-channel analyzer (MCA). The measurement procedures and activity calculations performed, were as described by [14]. Similarly, the assessment of radiation hazards: the radium equivalent activity $\left(\mathrm{Ra}_{\mathrm{eq}}\right)$, the absorbed gamma radiation dose rate in air (D), the annual effective dose (E), the external radiation hazard index $\left(\mathrm{H}_{\mathrm{ex}}\right)$.

\section{Assessment of Radiation Hazards}

\subsection{Radium Equivalent Activity}

The radiation hazards associated with the radionuclides are estimated by calculating the radium equivalent activity $\left(\mathrm{Ra}_{\mathrm{eq}}\right)$. It is a weighted sum of activities of ${ }^{226} \mathrm{Ra}$, ${ }^{232} \mathrm{Th}$ and ${ }^{40} \mathrm{~K}$; and it is based on the assumption that 370 $\mathrm{Bq} \cdot \mathrm{kg}^{-1}$ of ${ }^{226} \mathrm{Ra}, 259 \mathrm{~Bq} \cdot \mathrm{kg}^{-1}$ of ${ }^{232} \mathrm{Th}$ and $4810 \mathrm{~Bq} \cdot \mathrm{kg}^{-1}$ of ${ }^{40} \mathrm{~K}$ produce the same gamma radiation dose rate [18]. To avoid radiation hazards, materials whose $R a_{\mathrm{eq}}$ is greater than $370 \mathrm{~Bq} \cdot \mathrm{kg}^{-1}$ should not be used. $R a_{\text {eq }}$ is defined by the following formula:

$$
R a_{\mathrm{eq}}=A_{\mathrm{Ra}}+1.43 A_{\mathrm{Th}}+0.077 A_{\mathrm{K}}
$$

where $A_{\mathrm{Ra}}, A_{\mathrm{Th}}$ and $A_{\mathrm{K}}$ are the activity concentrations of ${ }^{226} \mathrm{Ra},{ }^{232} \mathrm{Th}$ and ${ }^{40} \mathrm{~K}$, respectively.

\subsection{Air Absorbed Gamma Radiation Dose Rate}

Effects of gamma radiation are normally expressed in terms of the absorbed dose rate in air, which originate from radioactive sources in the soil. The activity concentrations in soil correspond to total absorbed dose rate in air at $1 \mathrm{~m}$ above the ground level. The absorbed dose rate in air $(D)$ for the population living in the studied area is calculated using the following equation [18]:

$$
D=\left(F_{\mathrm{Ra}} \cdot A_{\mathrm{Ra}}+F_{\mathrm{Th}} \cdot A_{\mathrm{Th}}+F_{\mathrm{K}} \cdot A_{\mathrm{K}}\right) \times 10^{-6}
$$

where $D$ is the absorbed dose rate in air $\left(\mathrm{nGy} \cdot \mathrm{h}^{-1}\right)$ at $1 \mathrm{~m}$ height above the ground level. $F_{\mathrm{Ra}}, F_{\mathrm{Th}}$ and $F_{\mathrm{K}}$ are the dose conversion factors for ${ }^{226} \mathrm{Ra},{ }^{232} \mathrm{Th}$ and ${ }^{40} \mathrm{~K}$ respectively. They are taken as $4.27,6.62$ and 0.43 for ${ }^{226} \mathrm{Ra}$, ${ }^{232} \mathrm{Th}$ and ${ }^{40} \mathrm{~K}$ respectively as assessed by UNSCEAR [3].

\subsection{Annual Effective Dose}

The annual effective dose received by the population is calculated using the following formula:

$$
E=T \cdot Q \cdot D \times 10^{-6}
$$

where $D$ is the absorbed dose rate in air, $Q$ is the conversion factor of $0.7 \mathrm{~Sv} \cdot \mathrm{Gy}^{-1}$, which converts the absorbed dose rate in air to human effective dose received, and $T$ is the time for 1 year, i.e. $8760 \mathrm{hrs}$.

\subsection{Internal and External Radiation Hazard Index}

Radiation hazards due to natural radionuclides of ${ }^{40} \mathrm{~K}$, ${ }^{232} \mathrm{Th}$ and ${ }^{226} \mathrm{Ra}$ may be internal or external depending upon the location of a receptor indoor (inside a dwelling) or outdoor (outside a dwelling) on the ground. These hazards are defined in terms of internal or indoor and external or outdoor radiation hazard index and are denoted by $H_{\text {in }}$ and $H_{e x}$, respectively. These are computed by using the following expressions:

$$
\begin{aligned}
& H_{\text {in }}=\frac{A_{R a}}{185}+\frac{A_{T h}}{259}+\frac{A_{K}}{4810} \\
& H_{\text {ex }}=\frac{A_{R a}}{370}+\frac{A_{T h}}{259}+\frac{A_{K}}{4810}
\end{aligned}
$$

where $A_{K}, A_{T h}$ and $A_{R a}$ are the activity concentrations of ${ }^{40} \mathrm{~K},{ }^{232} \mathrm{Th}$ and ${ }^{226} \mathrm{Ra}$ respectively. The indoor hazard index is calculated to determine the radiation hazards from ${ }^{40} \mathrm{~K},{ }^{232} \mathrm{Th}$ and ${ }^{226} \mathrm{Ra}$. There are no wooden houses in Riyadh. All houses are built with soil and concrete. All floors are lined with soil beneath tiles. So, internal radia- 
tion hazard index has been calculated.

\section{Results and Discussion}

The mean values of measured activity concentrations of selected radionuclides of ${ }^{226} \mathrm{Ra},{ }^{232} \mathrm{Th}$ and ${ }^{40} \mathrm{~K}$ in sand samples from all twenty three sites in Ad-Dahna are shown in Table 1. The activity concentrations of ${ }^{226} \mathrm{Ra}$, ${ }^{232} \mathrm{Th}$ and ${ }^{40} \mathrm{~K}$ are in the range from $32.55-16.20 \mathrm{~Bq} \cdot \mathrm{kg}^{-1}$, 28.30 - $39.95 \mathrm{~Bq} \cdot \mathrm{kg}^{-1}, 333-533 \mathrm{~Bq} \cdot \mathrm{kg}^{-1}$, with a mean value of $23.4 \pm 4.3,29.7 \pm 5.9$ and $380 \pm 65 \mathrm{~Bq}^{-\mathrm{kg}^{-1}}$, respectively. The measured activity concentrations of ${ }^{226} \mathrm{Ra}$, ${ }^{232} \mathrm{Th}$ and ${ }^{40} \mathrm{~K}$ were compared with world-wide reported values as shown in Table 2 . It is found that the measured activity concentrations of the three naturally occurring radionuclides in this study are lower than most of the reported values from other countries as well as the world's average values. The results shown in Table $\mathbf{1}$ indicate that mean value of ${ }^{226} \mathrm{Ra}\left(23.4 \pm 4.3 \mathrm{~Bq} \cdot \mathrm{kg}^{-1}\right)<{ }^{232} \mathrm{Th}$ $\left(29.7 \pm 5.9 \mathrm{~Bq} \cdot \mathrm{kg}^{-1}\right)<{ }^{40} \mathrm{~K}\left(380 \pm 65 \mathrm{~Bq} \cdot \mathrm{kg}^{-1}\right)$.

Radium equivalent activity $\left(\mathrm{Ra}_{\mathrm{eq}}\right)$ owing to activity concentration of the three natural radionuclides from all sites varies from 90.5 to $119.5 \mathrm{~Bq} \cdot \mathrm{kg}^{-1}$. The mean value of $\mathrm{Ra}_{\mathrm{eq}}$ is $106 \pm 8 \mathrm{~Bq} \cdot \mathrm{kg}^{-1}$, which is much less than the threshold value of $370 \mathrm{~Bq} \cdot \mathrm{kg}^{-1}$. The mean values of air absorbed gamma radiation dose rate $(D)$, annual effective dose $\left(E_{\text {air }}\right)$, and external radiation hazard index $\left(H_{e x}\right)$ calculated in this work are shown in Table 2. It is shown that mean value of $D, E_{\text {air }}$ and $H_{\mathrm{ex}}$ are $51.4 \mathrm{nGy} \cdot \mathrm{h}^{-1}, 0.32$ $\mathrm{mSv} \cdot \mathrm{y}^{-1}$ and 0.13 respectively. Mean annual effective radiation dose of $0.32 \mathrm{mSv} \cdot \mathrm{y}^{-1}$ computed in this work is much less than the dose rate reported world-wide.

Table 1. Activity concentrations $\left(\mathrm{Bq} \cdot \mathrm{kg}^{-1}\right)$ of ${ }^{226} \mathrm{Ra},{ }^{232} \mathrm{Th}$ and ${ }^{40} \mathrm{~K}$ in sand samples; and their corresponding radium equivalent activity $\left(\mathrm{Ra}_{\mathrm{eq}}\right)$, Internal radiation hazard index $\left(H_{\mathrm{in}}\right)$, external radiation hazard index $\left(H_{\mathrm{ex}}\right)$, absorbed dose rate $(D)$ and annual effective dose $\left(E_{\text {air }}\right)$.

\begin{tabular}{|c|c|c|c|c|c|c|c|c|}
\hline \multirow{2}{*}{ Site } & \multicolumn{3}{|c|}{ Activity concentrations $\left(\mathrm{Bq} \cdot \mathrm{kg}^{-1}\right)$} & \multirow{2}{*}{$\mathrm{Ra}_{\mathrm{eq}}\left(\mathrm{Bq} \cdot \mathrm{kg}^{-1}\right)$} & \multirow{2}{*}{$H_{\text {in }}$} & \multirow{2}{*}{$H_{\mathrm{ex}}$} & \multirow{2}{*}{$D\left(\mathrm{nGy} \cdot \mathrm{h}^{-1}\right)$} & \multirow{2}{*}{$E_{\text {air }}\left(\mathrm{mSv} \cdot \mathrm{y}^{-1}\right)$} \\
\hline & ${ }^{226} \mathrm{Ra}$ & ${ }^{232} \mathrm{Th}$ & ${ }^{40} \mathrm{~K}$ & & & & & \\
\hline S 1 & 22.0 & 23.9 & 285 & 78.1 & 0.27 & 0.21 & 37.48 & 0.23 \\
\hline S 2 & 20.8 & 34.8 & 347 & 97.3 & 0.32 & 0.26 & 46.83 & 0.29 \\
\hline S 3 & 23.1 & 31.4 & 368 & 96.4 & 0.32 & 0.26 & 46.48 & 0.29 \\
\hline S 4 & 21.6 & 32.0 & 479 & 104.2 & 0.34 & 0.28 & 50.96 & 0.31 \\
\hline S 5 & 30.2 & 29.9 & 533 & 114.0 & 0.39 & 0.31 & 55.61 & 0.34 \\
\hline S 6 & 20.5 & 32.2 & 333 & 92.1 & 0.30 & 0.25 & 44.35 & 0.27 \\
\hline S 7 & 20.7 & 35.3 & 402 & 102.1 & 0.33 & 0.28 & 49.49 & 0.30 \\
\hline S 8 & 25.0 & 28.0 & 375 & 93.8 & 0.32 & 0.25 & 45.30 & 0.28 \\
\hline S 9 & 18.6 & 16.1 & 295 & 64.4 & 0.22 & 0.17 & 31.30 & 0.19 \\
\hline S 10 & 23.4 & 32.4 & 478 & 106.6 & 0.35 & 0.29 & 52.01 & 0.32 \\
\hline S 11 & 16.2 & 31.9 & 297 & 84.6 & 0.27 & 0.23 & 40.77 & 0.25 \\
\hline S 12 & 16.9 & 29.5 & 456 & 94.1 & 0.30 & 0.25 & 46.32 & 0.28 \\
\hline S 13 & 29.7 & 34.4 & 429 & 111.8 & 0.38 & 0.30 & 53.86 & 0.33 \\
\hline S 14 & 28.5 & 36.1 & 393 & 110.2 & 0.37 & 0.30 & 52.90 & 0.32 \\
\hline S 15 & 25.9 & 31.5 & 316 & 95.3 & 0.33 & 0.26 & 45.50 & 0.28 \\
\hline S 16 & 24.3 & 36.8 & 390 & 106.9 & 0.35 & 0.29 & 51.49 & 0.32 \\
\hline S 17 & 17.2 & 20.0 & 413 & 77.5 & 0.26 & 0.21 & 38.28 & 0.23 \\
\hline S 18 & 30.6 & 31.6 & 307 & 99.3 & 0.35 & 0.27 & 47.15 & 0.29 \\
\hline S 19 & 27.4 & 35.4 & 378 & 107.1 & 0.36 & 0.29 & 51.39 & 0.32 \\
\hline S 20 & 26.1 & 31.6 & 330 & 96.6 & 0.33 & 0.26 & 46.21 & 0.28 \\
\hline S 21 & 19.1 & 15.8 & 408 & 73.0 & 0.25 & 0.20 & 36.12 & 0.22 \\
\hline S 22 & 23.9 & 28.3 & 340 & 90.5 & 0.31 & 0.24 & 43.56 & 0.27 \\
\hline S 23 & 27.7 & 24.6 & 385 & 92.5 & 0.32 & 0.25 & 44.65 & 0.27 \\
\hline Mean & 23.4 & 29.7 & 380 & 95 & 0.32 & 0.26 & 46.00 & 0.28 \\
\hline Std & 4.3 & 5.9 & 65 & 13 & 0.04 & 0.03 & 6.11 & 0.04 \\
\hline UNSCEAR & 35 & 30 & 400 & 108.7 & 0.39 & 0.29 & 52.01 & 0.32 \\
\hline World-wide & $30 \pm 14$ & $37 \pm 20$ & $397 \pm 220$ & 113.5 & 0.39 & 0.31 & 54.38 & 0.33 \\
\hline
\end{tabular}


Table 2. Activity concentrations $\left(\mathrm{Bq} \cdot \mathrm{kg}^{-1}\right)$ of ${ }^{226} \mathrm{Ra},{ }^{232} \mathrm{Th}$ and ${ }^{40} \mathrm{~K}$ measured worldwide.

\begin{tabular}{ccccc}
\hline \multirow{2}{*}{ Ref. } & \multicolumn{3}{c}{ Activity concentration $\left({\left.\mathrm{Bq} \cdot \mathrm{kg}^{-1}\right)}\right.$} & Region \\
\cline { 2 - 4 } & ${ }^{40} \mathrm{~K}$ & $232 \mathrm{Th}$ & $226 \mathrm{Ra}$ & \\
\cline { 1 - 4 }$[19]$ & 398.3 & - & 26.3 & Taiwan \\
{$[6]$} & 425.5 & 33.3 & 70.3 & Malaysia \\
{$[7]$} & 528 & 27 & 24 & Italy \\
{$[20]$} & 200 & 10.6 & 8.1 & The Netherlands \\
{$[21]$} & - & 22.8 & 22.8 & Mexico \\
{$[8]$} & 842 & 27 & 24 & Hong Kong \\
{$[9]$} & 807 & 18 & 14.3 & Brazil \\
{$[22]$} & 714 & 26 & 24 & Zambia \\
{$[10]$} & 188 & 8 & 25 & Jordan \\
{$[23]$} & 188.1 & 14.6 & 25.1 & Jordan \\
{$[11]$} & 158 & 25 & 14 & Bangladesh \\
{$[24]$} & 456 & 64 & 44 & India \\
{$[25]$} & 367 & 17 & 18 & Greece \\
{$[12]$} & 618 & 21.4 & 25.3 & Egypt \\
{$[26]$} & 508.8 & 43.2 & 24.5 & Pakistan \\
{$[13]$} & 859 & 39 & 22.1 & China \\
{$[27]$} & 188 & 16 & 17 & Cuba \\
{$[28]$} & 586 & 31 & 14 & Cameroon \\
{$[15]$} & 441 & 26 & 44 & Turkey \\
\hline & & & &
\end{tabular}

\section{Conclusion}

The present study has been carried out to establish a base line data regarding concentration levels of naturally occurring radionuclides of ${ }^{226} \mathrm{Ra},{ }^{232} \mathrm{Th}$ and ${ }^{40} \mathrm{~K}$ in soils and the corresponding radiation doses in Riyadh, Saudi Arabia. Measured mean activity concentrations of the three radionuclides are found less than the world's average values. Calculated values of external radiation doses are also lower than the world average of about $0.5 \mathrm{mSv}$ per year. It is concluded that there is no potential radiological health risk associated with the soils of area investigated during this study. The data generated here may be useful for the introduction of radiation safety standards by the State Authorities for the protection of general population from radiation hazards owing to terrestrial sources.

\section{REFERENCES}

[1] M. J. Willson, "Anthropogenic and Naturally Occurring Radioactive Materials Detected on Radiological Survey of Properties in Monticello, Utah. Environmental Health Physics," 26th Midyear Topical Meeting, 24-28 January 1993, p. 564.

[2] United Nations Scientific Committee on the Effects of Atomic Radiation, "Sources and Effects of Ionising Radiation," Unscear Report, New York, 1993.
[3] United Nations Scientific Committee on the Effects of Atomic Radiation, "Exposures from Natural Radiation Sources," UNSCEAR Report, New York, 2000.

[4] M. Tzortzis, E. Svoukis and H. Tsertos, "A Comprehensive Study of Natural Gamma Radioactivity Levels and Associated Dose Rates from Surface Soils in Cyprus," Radiation Protection Dosimetry, Vol. 109, No. 3, 2004, pp. 217-224. doi:10.1093/rpd/nch300

[5] P. McDonald, G. T. Cook and M. S. Baxter, "Natural and Anthropogenic Radioactivity in Coastal Regions of the UK," Radiation Protection Dosimetry, Vol. 45, No. 1-4, 1992, pp. 707-710.

[6] S. Chong and G. U. Ahmad, "Gamma Activity of Some Building Materials in West Malaysia," Health Physics, Vol. 43, No. 2, 1982, pp. 272-273.

[7] G. Sciocchetti, F. Scacco, P. G. Baldassini, L. Monte and R. Sarao, "Indoor Measurements of Airborne Natural Radioactivity in Italy," Radiation Protection Dosimetry, Vol. 7, No. 1-4, 1984, pp. 347-351.

[8] M. Chung-Keung, L. Shun-Yin, A. Shui-Chun and N. WaiKwok, "Radionuclide Contents in Building Materials in Hong Kong," Health Physics, Vol. 57, No. 3, 1989, pp. 397-401.

[9] A. Malanca, V. Pessina and G. Dallara, "Radionuclide Content of Building Materials and Gamma Ray Dose Rates in Dwellings of Rio Grande Do Norte, Brazil," Radiation Protection Dosimetry, Vol. 48, No. 2, 1993, pp. 199-203.

[10] A. J. A. H. Khatibeh, A. Maly, N. Ahmad and Matiullah, "Natural Radioactivity in Jordanian Construction Materials," Radiation Protection Dosimetry, Vol. 69, No. 2, 1997, pp. 143-147. doi:10.1093/oxfordjournals.rpd.a031895

[11] M. I. Chowdury, M. N. Alam and A. K. S. Ahmed, "Concentration of Radionuclides in Building and Ceramic Materials of Bangladesh and Evaluation of Radiation Hazard," Journal of Radioanalytical and Nuclear Chemistry, Vol. 231, No. 1-2, 1998, pp. 117-123. doi: $10.1007 / \mathrm{BF} 02388016$

[12] A. M. El-Arabi, "Natural Radioactivity in Sand Used in Thermal Therapy at the Red Sea Coast," Journal of Environmental Radioactivity, Vol. 81, No. 1, 2005, pp. 1119. doi:10.1016/j.jenvrad.2004.11.002

[13] X. W. Lu and X. L. Zhang, "Measurement of Natural Radioactivity in Sand Samples Collected from the Baoji Weihe Sands Park, China," Environmental Geology, Vol. 50, No. 7, 2006, pp. 977-982.

[14] A. S. Alaamer, "Assessment of Radiological Hazards Owing to Natural Radioactivity Measured in Soil of Riyadh, Saudi Arabia," Turkish Journal of Engineering \& Environmental Sciences, Vol. 32, 2008, pp. 229-234.

[15] U. Cevik, N. Damla, A. I. Koby, N. Celik, A. Celik and A. A. Van, "Assessment of Natural Radioactivity of Sand Used in Turkey," Journal of Radiological Protection, Vol. 29, No. 1, 2009, p. 61. doi:10.1088/0952-4746/29/1/004

[16] R. Trevisi, M. Bruno, C. Orlando, R. Ocone, C. Paolelli, M. Amici, A. Altieri and B. Antonelli, "Radiometric Characterization of More Representative Natural Building Materials in the Province of Rome," Radiation Protection 
Dosimetry, Vol. 113, 2005, pp. 168-172. doi:10.1093/rpd/nch438

[17] G. Gonzalez-Chornet and J. Gonzalez-Labajo, "Natural Radioactivity in Beach Sands from Donana National Park and Mazagon (SPAIN)," Radiation Protection Dosimetry, Vol. 112, No. 2, 2004, pp. 307-310. doi:10.1093/rpd/nch397

[18] Matiullah, A. Ahad, S. ur Rehman, S. ur Rehman and M. Fahee, "Measurement of Radioactivity in the Soil of Bahawalpur Division, Pakistan," Radiation Protection Dosimetry, Vol. 112, No. 3, 2004, pp. 443-447. doi:10.1093/rpd/nch409

[19] T. Y. Chang, W. L. Cheng and P. S. Weng, "Potassium Uranium, and Thorium Contents in Building Material of Taiwan," Health Physics, Vol. 27, No. 4, 1974, pp. 385387.

[20] J. G. Ackers, J. F. Den-Boer, P. De-Jong and R. A. Wolschrijn, "Radioactivity and Radon Exhalation Rates of Building Materials in the Netherlands," Science of the Total Environment, Vol. 45, 1985, pp. 151-156. doi:10.1016/0048-9697(85)90215-3

[21] G. Espinosa, J. I. Golzarri, I. Gamboa and I. Jacobson, "Natural Radioactivity in Mexican Building Material by SSNTD," Nuclear Tracks and Radiation Measurements, Vol. 12, No. 1-6, 1986, pp. 767-770. doi:10.1016/1359-0189(86)90699-0

[22] P. Hayumbu, M. B. Zaman, N. C. H. Lubaba, S. S. Munsanje and D. Nuleya, "Natural Radioactivity in Zambian Building Materials Collected from Lusaka," Journal of Radioanalytical and Nuclear Chemistry, Vol. 199, No. 3, 1995, pp. 229-238. doi:10.1007/BF02162371
[23] A. N. Matiullah and A. J. A. J. Hussain, "Natural Radioactivity in Jordanian Soil and Building Materials and the Associated Radiation Hazards," Journal of Environmental Radioactivity, Vol. 39, No. 1, 1998, pp. 9-22. doi:10.1016/S0265-931X(97)00046-5

[24] V. Kumar, T. V. Ramachandran and R. Prasad, "Natural Radioactivity of Indian Building Materials and By-Products," Applied Radiation and Isotopes, Vol. 51, No. 1, 1999, pp. 93-96. doi:10.1016/S0969-8043(98)00154-7

[25] S. Stoulos, M. Manolopoulou and C. Papastefanou, “Assessment of Natural Radiation Exposure and Radon Exhalation from Building Materials in Greece," Journal of Environmental Radioactivity, Vol. 69, No. 3, 2003, pp. 225-240. doi:10.1016/S0265-931X(03)00081-X

[26] K. Khalid, P. Akhter and S. D. Orfi, "Estimation of Radiation Doses Associated with Natural Radioactivity in Sand Samples of the North Western Areas of Pakistan Using Monte Carlo Simulation," Journal of Radioanalytical and Nuclear Chemistry, Vol. 265, No. 3, 2005, pp. 371-375. doi:10.1007/s10967-005-0835-1

[27] F. O. Brigido, E. N. Montalvan and Z. J. Tomas, "Natural Radioactivity in Some Building Materials in Cuba and Their Contribution to the Indoor Gamma Dose Rate," Radiation Protection Dosimetry, Vol. 113, No. 2, 2005, pp. 218-222. doi:10.1093/rpd/nch434

[28] M. Ngachin, M. Garavaglia, C. Giovani, M. KwatoNjock G. and A. Nourreddine, "Assessment of Natural Radioactivity and Associated Radiation Hazards in Some Cameroonian Building Materials," Radiation Measurements, Vol. 42, No. 1, 2007, pp. 61-67. doi:10.1016/j.radmeas.2006.07.007 